\title{
CORRUPTION IN FRANCE
}

\section{PhD. Natasha Georgieva Hadji Krsteski \\ natashageorgievaivanovska@gmail.com}

\author{
Professional Paper \\ doi:10.5937/jouproman4-10970
}

\begin{abstract}
In accordance with the research conducted by Transparency International, in the period from 2009 until 2012, it is found that this European country did not undergo drastic changes during this period, when it comes to its ranking.
\end{abstract}

According to this research, France belongs to the countries that undertake appropriate measures for the fight against corruption - and it is at a satisfactory level in modern conditions, even in well-developed countries.

Corruption in France rests on three major authorities: the Financial Intelligence Unit, the Central Service for the Prevention of Corruption (SCPC) and the Central Brigade for the Fight against Corruption (BCLC).

As a result of the good institutional cooperation, France is prepared to prevent corruption in the state authorities.

The international community disposes of data that refer to the detrimental and difficult consequences caused by corruption. Such findings led to two key issues - prevention of corruption and fight against corruption, not only in France, but in other countries as well.

In order to overcome this large-scale problem, many international documents have been adopted, ratified by the Republic of Macedonia. authorities

Key words: corruption, France, state

\section{INTRODUCTION}

Corruption belongs to the group of terms that are difficult to define, because its content changes depending on the time, social and political order.

It is a phenomenon that undermines the political stability, the people's trust in political and judicial system, in a legal state, economic development, foreign investments and integration of the country.

The meaning of the term corruption is related to the Latin term "Corruption" or the root of the word "rumpere". The term "coruptio" means someone's destruction or corruption. While the term "rumpere" implies infringement, breach, that is, a breach of an administrative, social or moral norm.

There are interpretations according to which corruption was created as a compound noun of the part "cor" which means a treaty, an agreement, verification, while the second part originates from the verb "rompere" which means to break, or violate. Therefrom a conclusion follows that widely speaking, corruption would be "a verification to break (some order)".

The political and the moral, socialeconomic crisis, the interethnic impatience, the complex security condition, the politicization of the state institutions, encourage the citizens' wish to quickly get rich. The only salvation they see is corruption in general, because this is the simplest way to realize their desire for money, property and power.

Corruption hinders democratic development, it threatens the basic rights and freedoms of the human and the citizen, it infringes competition that contributes for low economic development and threatens the rule of law.

Interesting information is the one that emphasizes that at global level there is a lack of in-depth research about the economic, political and other harmful implications of corruption.

Corruption can be observed from different aspects. It can be argued from legal, sociological, philosophic and religious aspect. 
The most general definition of corruption is the following - The term corruption implies: depravity, depraved, perversion, promiscuity, bribery, depravation, decay, decomposition, forgery (writings, measures etc. $)^{\mathbf{1}}$

Corruptive actions are considered actions regulated by legal regulations and by-laws. Therefrom the following arises every human behavior that is not prohibited by law cannot be considered a corruptive act, while every violation of the legally defined standards is corruption.

The issues that are related and refer to corruption and organized crime in general, should be addressed to the country and its authorities. If corruption and organized crime rule a country, and the country does not undertake any measures for its reduction of suppression, this means that the country does not want or must not punish the ones who are directly involved in such large-scale problem.

The fight against corruption will be successful only with courage and by indicating all the drawbacks of the state authorities that are specialized to fight against this evil. If the priority objective is achieved - independence of the authorities that are specialized for fight against corruption, only in such case we can hope for and expect reduction of corruption in general and possibility for democracy to act. In modern conditions, when corruption is defined as a novelty, the criterion of public opinion is considered. In modern conditions, democracy is given advantage, so that the general public can decide which behavior is corruptive and which one is not. Corruption is undergoing growth at the moment, which shows that it is not something exclusive, on the contrary, it is a problem for the development of the countries. Every day throughout the world, information are published about international corruption affairs,

\footnotetext{
1 Vujaklija, M., Lexicon of foreign words and phrases, Prosveta, Belgrade, 1994/95, pg. 236.
}

involvement of politicians, holders of administrative and executive functions of highest rank of specific countries.

\section{CORRUPTION IN FRANCE}

In the Republic of France pursuant to the Law no. 93 - 122 from 29.01.1993 that refers to prevention of corruption and transparency of the economic life and public procedures, the Central Service for the Prevention of Corruption is obliged to provide all required information aimed at detection and prevention both of active, as well as of passive corruption, bribery by people who are holders of a public function, as well as by natural persons, fraud or embezzlement.

The Central Service that is responsible for the prevention of corruption is a service with interministerial composition and it is under the direct authority of the first person of the Ministry of Justice. Its modalities of application are determined by decree no. $93-232$ from 22.02.1993. It is authorized and obliged to help in the following circumstances - to provide assistance to the judicial authorities that deal with this problematic at their request, as well as to give an opinion to the judicial authorities at their request about the specific measures that they should undertake in order to prevent corruption. $^{2}$

In addition, at the request of the state prosecution and the investigative courts that deal with some of the occurrences that we determined in the previous paragraph, the Service announces them the required information (let me just clarify that pursuant to this law, among other things, article 4 emphasizes that these facts are created during a discussion and they imply only plain data). ${ }^{3}$

\footnotetext{
2 Business Anti-Corruption Portal, (2013), "Snapshot of the France Country Profile", GAN Integrity Solutions, Paris, p. 123

3 Radio France Internationale, (2012), Paris publishing, Paris, p. 154,
} 
The fight against corruption in France rests on three basic authorities ${ }^{4}$, established by law, including the Financial Intelligence Unit (TRACFIN - Traitement $\mathrm{du}$ renseignement et action contre les circuits financiers clandestins), which is part of the Ministry of Finance; the Central Service for the Prevention of Corruption (SCPC), which states its opinion when it comes to projects for undertaking appropriate preventive measures in an event of active and passive corruption. Here I would like to point out that this authority increases its international coverage, and the Central Brigade for the Fight against Corruption (BCLC) which is part of the Ministry of Interior and it is competent to act in all investigative actions that actually refer to the occurrence of corruption.

At an international level, France is one of the first that ratified the OCDE Convention $^{5}$ and a second EU member that ratified the UN Convention against Corruption. ${ }^{6}$

Pursuant to Article 432 - 11 of the Criminal Code of the Republic of France, a prison sentence of ten years and a fine in an amount of 150,000 Euros is stipulated for an act committed by a governmental representative ${ }^{7}$, who illegally requests or approves, directly or indirectly, any benefit (promises and gifts), for his personal benefit or for someone else, regardless of whether he committed an act or it was already committed previously from his office or his mandate, or if he abuses something as a result of his influence. ${ }^{8}$

\footnotetext{
${ }^{4}$ http://www.transparency-france.org/

${ }^{5}$ EU Anti-Corruption Report - France 2014 Europa.eu

${ }^{6}$ Second Compliance Report on France; Greco RCIII (2013) 3E, p. 15

7 GRECO (2011) Third Evaluation Round. Compliance Report on France. Strasbourg: Council of Europe, 1st April, see especially pp 10-17.

${ }^{8}$ UNCAC Implementation Review (2011) Résumé analytique: rapport de la France. Vienna: UN, p. 5.
}

Article 433 - 11 stipulates a prison sentence of ten years and a fee in an amount of 150,000 Euros, for a committed action by a person who illegally, directly or directly, at any moment, offers to a governmental representative gifts, promises or any other material or immaterial benefit.

The same penalty applies for a procedure wherewith "a person who is a governmental representative and is responsible for public duties or who is entrusted with an electoral state mandate", who illegally offers gifts or any other benefit, if he performed or will perform in the future, willingly or unwillingly, actions within the function that was entrusted to him, as well as when this person abuses or already abused his/her influence, in regard to acquisition of governmental positions, markets or any other useful solution.

As a result of the findings of the international community about the detrimental and difficult consequences caused by corruption both in France, as well as in other countries, a reaction on two issues followed - prevention of corruption and fight against corruption.

In order to overcome this large-scale problem, the following conventions have been adopted: OCDE Convention signed on 17.12.1997 aimed at combating bribery of foreign officials in international business transactions; ${ }^{10}$ Conventions of the Council of Europe, Criminal Law Convention for fight against corruption adopted on 27.01.1999 and Civil Law Convention from 04.11.1999; ${ }^{11}$

\footnotetext{
${ }^{9}$ CNCDH (2013), Avis sur l'independence de la justice, JORF ${ }^{\circ} 0176$, p. 13

${ }^{10}$ Association Française des magistrats instructeurs (AFMI) (2011) Les enquêtes économiques et financières sont en danger à Paris, p. 16

${ }^{11}$ OECD (2012) Phase 3 Report on Implementing the OECD Anti-Bribery Convention in France, p. 43.
} 
UN Convention against Corruption adopted on $31.10 .2003 ;^{12}$ and the Researches of FATF-GAFI (Financial Action Task Force).

Due to the very negative results in the country, France was equipped with an original mechanism, which I have mentioned previously in the contents, which is the Central Service for the Prevention of Corruption (SCPS). This authority is not authorized to do research, and this means that it does not have a research function. Its authorizations are directed towards the collection of information, complete processing of information, aimed at familiarization with the essence of this universal evil in France. The Central Service for the Prevention of Corruption may be engaged by political, administrative or judicial authorities, which may ask its opinion on different situation or about an ongoing research. Through this service France can offer its expertise and assistance to other countries, of course if they want this, in order to provide growth of the efficiency of the mechanisms for prevention and fight against corruption. The international action of the Central Service for the Prevention of Corruption has developed positively over the years. SCPS participates in the researches that are being conducted by several international organizations such as GRECO (Group of States against Corruption), ONUDC (United Nations Office on Drugs and Crime) and OCDE (Organisation for Economic Cooperation and Development).

The Central Service prepares an Annual Report, which it further delivers to the Prime Minister of France and the Minister of Justice. The Central Service indicates its entire activity in the report. The report among other things contains various proposals and thematic analyses which are being prepared on the basis of

\footnotetext{
${ }^{12}$ OECD (2012) Phase 3 Report on implementing the OECD Anti-Corruption Convention on France, p. 65
}

the years of the risk sectors in terms of corruption.

The research conducted by Transparency International from 2009 until 2012 indicates that during these years France did not undergo drastic changes in terms of its ranking. In the research conducted for 2009, France is positioned $24^{\text {th }}$. In 2010 it was on the $25^{\text {th }}$ position. The following year it had the same ranking, $25^{\text {th }}$ position, while in 2012 it was positioned $22^{\text {nd }}$, which means a slight fall of its ranking, which on the other hand indicates that necessary measures have been undertaken for the commencement of a gradual reduction, and suppression of corruption of one of the most developed European countries. In total, according to the research conducted by Transparency International, France belongs to the countries that undertake the appropriate measures against the consequences that occur as a result of the "rule" of the universal evil - corruption. This country will continue to undertake appropriate measures for profound resolution of this problem in the future, and if possible, for its complete eradication in all spheres of social life.

\section{CONCLUSION}

France has ratified several important international conventions for fight against corruption, such as the OECD convention for fight against foreign public officials in the international business transactions and the UN Convention against Corruption. In general, the investors do not consider that corruption is a problem for doing business in France and the companies that work in France usually have good reputation of corporate social responsibility. Still, in the past couple of years there are corruption scandals with public officials. The public matters and the defense industry are considered most affected by corruption. 


\section{USED LITERATURE}

1. Association Française des magistrats instructeurs (AFMI) (2011) Les enquêtes économiques et financières sont en danger à Paris,

2. Business Anti-Corruption Portal, (2013), "Snapshot of the France Country Profile", GAN Integrity Solutions, Paris,

3. CNCDH (2013), Avis sur l'independence de la justice, JORF n ${ }^{\circ} 0176$,

4. EU Anti-Corruption Report - France 2014 - Europa.eu

5. GRECO (2011) Third Evaluation Round. Compliance Report on France. Strasbourg: Council of Europe,

6. OECD (2012) Phase 3 Report on Implementing the OECD Anti-Bribery Convention in France,
7. OECD (2012) Phase 3 report on implementing the OECD Anti-Corruption Convention on France,

8. Radio France Internationale, (2012), Paris publishing, Paris,

9. Second Compliance Report on France; Greco RC-III (2013) 3E,

10. UNCAC Implementation Review (2011) Résumé analytique: rapport de la France. Vienna: UN,

11. Vujaklija, M., (1994/95), Lexicon of foreign words and phrases (Лексикон страних речи и израза), Prosveta, Belgrade

Internet sources:

1. http://www.transparency-france.org/ 